\title{
Obludná nadvláda žen nad životem a tvorbou Johna Knoxe
}

\author{
MIROSLAV BENEŠ
}

\begin{abstract}
Beneš, Miroslav: Monstrous Regiment of Women over the Life and Work of John Knox
John Knox was a Scottish scholar, reformer, promoter of the Presbyterian Church and a critic of the female sovereigns who ruled over England and Scotland in the $16^{\text {th }}$ century. Being a French galley slave, repeated exile, persecution of Protestants and being accused of heresy affected John Knox so severely over the years that he composed one of his most famous political writings The First Blast of Trumpet against the Monstrous Regiment of Women as a critique of the rule of the English Queen Mary Tudor and Scottish Queen Dowager Mary de Guise. For decades, Knox's work and personal life were shaped by women's supremacy. Therefore, the aim of this research, is to describe the consequences of the intensive interactions between John Knox and the female sovereigns.
\end{abstract}

Key Words John Knox; Scottish Reformation; Gender; $16^{\text {th }}$ Century; Scotland; England doi.org/10.15452/Historica.2020.11.0002

Contact Univerzita Hradec Králové; miroslav.benes@uhk.cz

John $K_{n o x}{ }^{1}$ se do anglických a skotských dějin 16. století zapsal jako bouřlivý kazatel, reformátor, zakladatel skotské presbyteriánské církve a jako jeden z nejsilnějších kritiků žen panovnic. I když to v počátcích své církevní dráhy nemohl tušit, byla to právě vláda anglických a skotských královen, která tak výrazně ovlivnila nejen jeho osobní život, ale také obsah jeho kázání a směřování jeho církevních a politických spisů. Už tak dosti napjaté vztahy mezi Johnem Knoxem a královnami Anglie a Skotska vyhrotil do ještě větších extrémů jeho politický spis První zatroubení polnic proti obludné nadvládě žen vydaný roku 1558. ${ }^{2}$ Jak napovídá již samotný název této výzkumné studie, popř. jméno Knoxova politického spisu, cílem této práce je zodpovězení otázky: Jakým způsobem ovlivňovala ženská vláda Knoxův osobní i profesionální život? Z tohoto důvodu není předmětem zkoumání ani tak analýza a následná interpretace Knoxových argumentů, jako spíše představení jeho životní a tvůrčí cesty významného reformátora, které by ukázalo provázanost a nejspíše i jistou osudovost jeho vztahu k ženské otázce.

\footnotetext{
1 Johnu Knoxovi se ve svých pracích věnuje DAWSON, Jane: John Knox. New Haven 2015; TÁŽ: Scotland Re-formed, 1488-1587. Edinburgh 2007; MASON, Roger: John Knox and the British Reformation. Ashgate 1998; MASON, Roger: John Knox on Rebellion. Cambridge 1994; DONALDSON, Gordon: The Scottish Reformation. Cambridge 1960.

2 V originálu The First Blast of Trumpet against the Monstrous Regiment of Women. Autorem všech citovaných překladů Knoxových děl a korespondence je tvůrce této studie.
} 


\section{Zdroj Knoxova nepřátelství a kritiky}

John Knox začal svou církevní dráhu jako student teologie na univerzitách v Glasgow a Saint Andrews, kde se seznámil s významným skotským kazatelem Georgem Wishartem. Ten mladého Knoxe přesvědčil o nezbytnosti nápravy skotské katolické církve a také jej získal pro šíření protestantské víry. George Wishart vnímal Johna Knoxe jako svého chráněnce, a proto se ho během let snažil zasvětit do tajů skotské politické scény 16 . století a poukázat přitom na její silnou provázanost se stále bohatším skotským katolickým kněžstvem. Pro svou kritiku církve a šíření protestantismu byl ale George Wishart roku 1546 uvězněn a následně odsouzen a upálen jako kacír. Tato událost mezi skotskými protestanty rozdmýchala vlnu nepokojů, které vedly až k zavraždění Wishartova soudce a věznitele, katolického kardinála Beatona. ${ }^{3}$

Nepokoje náboženského a politického charakteru nebyly ve Skotsku ničím novým. John Knox se ale popisované protestantské msty nezúčastnil, protože v dané době putoval např́ič Skotskem jako potulný kazatel a snažil se šiřiit protestantské učení. Po završení této poutě se ale přidal k protestantům, kteří nesli vinu za smrt kardinála Beatona, a byl spolu s nimi zadržen francouzskou armádou a odeslán jako vězeň na galeje, kde strávil dalších devatenáct měsíců. ${ }^{4}$ Jak zbytečná smrt Knoxova mentora, tak jeho nespravedlivé uvěznění byly jen dalšími důkazy, že kritika stávajících poměrů byla oprávněná. Proč ale Beatonovy vrahy zadržela právě francouzská, a nikoliv skotská armáda?

Spojenectví mezi Francií a Skotskem bylo v průběhu 16. století již téměř tradičním spojeneckým svazkem, který obě království spojoval v boji proti Anglii. Tato stará aliance dlouhodobě zavazovala Francii a Skotsko k napadení anglických hranic v př́padě, že Anglie zahájí vojenské akce proti jednomu ze zmíněných království. V př́ípadě anglického útoku na Francii tak skotská armáda měla napadnout severoanglickou hranici a přimět tak Anglii k riskantnímu boji na dvou frontách. ${ }^{5}$ Toto spojenectví bylo v průběhu 16 . století hned dvakrát posíleno - poprvé sňatkem skotského krále Jakuba V. Stuarta ${ }^{6} \mathrm{~s}$ francouzskou šlechtičnou Marií de Guise, ${ }^{7}$ a podruhé sňatkem dcery již zmíněného Jakuba V. Marie Stuartovny $^{8} \mathrm{~s}$ francouzským dauphinem a pozdějším králem Františkem II. ${ }^{9}$ Vojenská střetnutí mezi Anglií, Francií a Skotskem probíhala i v popisovaném období, a proto bylo francouzské armádě umožněno, aby zřídila vojenské posádky v blízkosti anglo-skotské hranice, v jejichž blízkosti se nacházeli zadržení protestanti včetně Johna Knoxe. Skotský král Jakub V. zemřel již v roce 1542 a jeho jediná dcera byla touto dobou nezletilá, a proto

\footnotetext{
DAWSON, J.: John, s. 28-37.

4 Tamtéž, s. 53-58.

5 WORMALDOVÁ, Jenny: Dějiny Skotska. Praha 2007, s. 100-101.
}

6 Jakubovi V. z rodu Stuartovců se ve svých výzkumech věnovali např́klad THOMAS, Andrea: The Princelie Majestie: The Court of James V of Scotland, 1528-1542. Edinburgh 2005; CAMERON, Jamie: James V. East Lothian 1998; WILLIAMS, Janet: Stewart Style, 1513-1542 : Essays on the Court of James V. East Lothian 1996.

7 O Marii de Guise např. CARROLL, Stuart: Martyrs and Murderers : The Guise Family and the Making of Europe. Oxford 2009; MERRIMAN, Marcus: The Rough Wooings : Mary Queen of Scots, 1542-1551. East Ponton 2000 .

8 Marii Stuartovně se věnovali např. WARNICKE, Retha: Mary Queen of Scots. London 2006; DUNN, Jane: Elizabeth and Mary: Cousins, Rivals, Queen. New York 2004; GUY, John: Queen of Scots : The True Life of Mary Stuart. Boston 2004; WORMALD, Jenny: Mary, Queen of Scots: Pride, Passion and a Kingdom Lost. London 2001.

$9 \quad$ Františkovi II. se ve svých dílech věnoval BAUMGARTNER, Frederic: France in the Sixteenth Century. New York 1995; HOLT, Mack: The French Wars of Religion. Cambridge 1995. 
zemi spravovali vybraní správci a protektoři, vedle nichž si však velký vliv udržovala také královna-vdova Marie de Guise, jejíž vazby na Francii byly logicky velmi silné.

Devatenáct měsíců strávených ve francouzském zajetí poskytlo Knoxovi dostatek času na úvahy o protestantské víře, o odkazu jeho upáleného učitele, ale také o jeho vztahu k Francii, který se v pozdější tvorbě ukázal jako dosti negativní. John Knox se po skončení trestu nevrátil do rodného Skotska, ale vydal se do protestantské Anglie, kde pokračoval v církevní dráze ve službách krále Edwarda VI. z rodu Tudorovců. ${ }^{10}$ Své anglické působení Knox vnímal jako jednu z nejlepších etap svého života, nebot' se mohl věnovat své práci, širrit protestantské učení bez větších problémů a jeho názory na otázky víry byly obecně ctěny. Po letech klidu však přišla další životní etapa, která změnila způsob Knoxova uvažování o světě. V roce 1553 totiž Edward VI. zemřel a na královský trůn usedla jeho nevlastní sestra Marie, ${ }^{11}$ která byla dcerou Jindřicha VIII. ${ }^{12}$ a jeho první ženy Kateřiny Aragonské. ${ }^{13}$

Marie I. Tudorovna v očích Johna Knoxe v podstatě představovala zosobnění Božího trestu seslaného na Anglii. Bylo známo, že si i v průběhu bratrovy protestantské vlády nechávala sloužit soukromé katolické mše, a proto se nedalo předpokládat, že by po vzoru svého otce a bratra pokračovala v podpoře protestantismu. Kromě toho ale byla Marie I. Tudorovna také ženou na královském trůnu, čímž se podle Knoxe protivila Božím i přírodním zákonům, protože si přisvojovala královskou autoritu, na níž měli právo pouze muži. ${ }^{14}$ John Knox ještě ve svých modlitbách a kázáních za zemřelého Edwarda VI. prosil Boha, aby Marii Tudorovnu osvítil a přiměl ji k přestoupení na protestantskou víru, jeho modlitby však nebyly vyslyšeny. ${ }^{15}$ Již krátce po nástupu na anglický trůn Marie I. Tudorovna otevřeně vystoupila proti protestantské víře a prostřednictvím náboženských zákonů v Anglii obnovila dřívější katolické mše. V podstatě tak s pomocí parlamentu zrušila výnosy a nařízení z dob vlády Jindřicha VIII. a Edwarda VI. a poté prostřednictvím vlastních zákonů obnovila staré vazby na Řím. ${ }^{16} \mathrm{~V}$ důsledku toho logicky došlo ke zlepšení vztahů s evropskými katolickými zeměmi a s Rímem, ale také k vlně nespokojenosti v řadách anglických protestantů, kterým Marie dala prostřednictvím svých náboženských

$10 \quad$ O Edwardovi VI. se můžeme více dočíst in: SKIDMORE, Chris: Edward VI: The Lost King of England. New York 2007; MacCULLOCH, Diarmaid: The Boy King : Edward VI and the Protestant Reformation. New York 2001; LOACH, Jennifer: Edward VI. New Haven 1999.

11 Marii I. Tudorovně se věnují např. EDWARDS, John: Mary I : England's Catholic Queen. New Haven 2011; DUFFY, Eamon: Fires of Faith: Catholic England under Mary Tudor. New Haven 2009; RICHARDS, Judith: Mary Tudor. London 2008; PORTER, Linda: The Myth of „Bloody Mary“ : A Biography of Queen Mary I of England. NewYork 2007; LOADES, David: The Reign of Mary Tudor. London 1991; TITTLER, Robert: The Reign of Mary I. London 1991.

12 Jindřichovi VIII. se věnovali např. WILSON, Derek: Henry VIII. London 2009; WOODING, Lucy: Henry VIII. London 2009; RIDLEY, Jasper: Henry VIII : The Politics of Tyranny. New York 1985; SMITH, Lacey: Henry VIII: The Mask of Royalty. Chicago 1982; ERICKSON, Carolly: Great Harry : The Extravagant Life of Henry VIII. New York 1980.

13 Kateřině Aragonské se ve svých výzkumech věnoval např. TREMLETT, Giles: Catherine of Aragon: The Spanish Queen of Henry VIII. New York 2010; LOADES, David: Mary Tudor : A Life. London 1992; WARNICKE, Retha: Women of the English Renaissance and Reformation. Greenwood 1983; PAUL, John: Catherine of Aragon and Her Friends. New York 1966.

14 MARLOW, Marvin (eds.): The Political Writings of John Knox. Washington 1985, s. 42-43.

15 LAING, David (eds.): The Works of John Knox, 3. Edinburgh 1846, s. 77-110.

16 TANNER, Joseph (eds.): Tudor Constitutional Documents A. D. 1485-1603 with an Historical Commentary. Cambridge 1922, s. 121-122. 
zákonů na výběr - bud' přestoupit zpět na katolickou víru a zachovat si tak postavení, majetek atd., nebo si ponechat vyznání, ale opustit své majetky a odejít do exilu. ${ }^{17}$

Převážná většina poddaných samozřejmě zůstala v Anglii, vrátila se ke katolické víře a i nadále žila pod Mariinou vládou. Necelých tisíc protestantů se ale rozhodlo odejít do kontinentální Evropy, kde hledali útočiště v různých protestantských městech a zkoušeli začít znovu. John Knox byl samozřejmě jedním z těchto exulantů a jeho kroky jej postupem času zavedly až do jednoho z nejvýznamnějších center dobového protestantismu, do švýcarské Ženevy.

V čase jeho neprrítomnosti Marie Tudorovna v Anglii pokračovala jak v upevňování svého mocenského postavení, tak v podpoře katolické víry. Toho dosahovala prostřednictvím zákonů a z nich vyplývajících perzekucí. $Z$ těchto zákonů a nařízení můžeme jmenovat například První zákon o velezradě proti královně Marii, Zákon o královské moci a Zákon oživující kacířské zákony. ${ }^{18}$ Již během prvních let její vlády tak bylo trestáno, když se lidé nehezky vyjadřovali o své panovnici, napadali její nároky na anglickou korunu apod. ${ }^{19}$ Oživením kacířských zákonů Marie v podstatě zahájila období náboženské perzekuce, kvůli níž časem získala přízvisko Marie Krvavá (orig. Bloody Mary). ${ }^{20}$ Vedle toho se Zákon o královské moci vztahoval ke zcela jinému tématu, a to k Mariinu sňatku se španělským králem a jejím bratrancem Filipem II. ${ }^{21}$ Tento svazek byl veřejností obecně přijímán velmi negativně, dokonce hrozila povstání a další nepokoje. Marie se též obávala zpochybňování svých nároků na anglický trůn, a proto nechala samotným zákonem potvrdit, že [...] koruna této ř́š́e spolu se všemi hodnostmi, poctami, privilegii, úřady, soudními pravomocemi a výsadami byla spojena [...] božskou prozřetelností všemohoucího Boha [...] sjejí královskou Výsostí, která je pravou a nespornou následnicí a dědičkou [...]. ${ }^{22}$

\section{Práce na Prvním zatroubení}

John Knox se o Mariiných činech a nově zavedené perzekuci anglických protestantů dozvěděl od nově příchozích exulantů, kteří postupně přicházeli do švýcarské Ženevy. Nejspíše právě v této době se Knox začal intenzivně zabývat otázkou, zda ženy opravdu mohou vládnout mužům $\mathrm{z}$ pozice královen. ${ }^{23} \mathrm{~S}$ touto otázkou se dokonce obrátil na zkušené reformátory Jana Kalvína ${ }^{24}$ a Heinricha Bullingera. Na základě jejich odpovědí a vlastních znalostí Písma začal John Knox pracovat na tom, aby světu jasně ukázal, že vláda žen je natolik špatná, že by neměla mít delšího trvání. V tomto směru nebyl jediným, kdo usiloval o vydání kritického díla namířeného proti dobovým královnám.

\footnotetext{
17 Tamtéž, s. 122-125.

18 Tamtéž, s. 122-123, 125, 406-407.

19 Tamtéž, s. 406-407.

20 Tamtéž, s. 125.

21 Španělskému králi Filipovi II. se ve svých výzkumech věnoval například PATTERSON, Benton: With the Heart of a King : Elizabeth I of England, Philip II of Spain, and the Fight for a Nation's Soul and Crown. New York 2007; PARKER, Geoffrey: The Grand Strategy of Philip II. New Haven 2000; KAMEN, Henry: Philip of Spain. New Haven 1999; LOADES, David: The Reign of Mary Tudor. London 1991.
}

22 TANNER, J. (eds.): Tudor Constitutional Documents, s. 122-123.

23 LAING, D. (eds.): The Works, 3, s. 222.

24 Z historiků zkoumajících životní osudy Jana Kalvína můžeme zmínit například SELDERHUS, Herman: John Calvin : A Pilgrim's Life. Downers Grove 2009; PARKER, Thomas: John Calvin : A Biography. Philadelphia 2007; McGRATH, Alister: A Life of John Calvin. Oxford 1990; BOUWSMA, William: John Calvin. Oxford 1988. 
Na srovnatelném traktátu pracoval také Knoxův prrítel a pastor anglických protestantů žijících v Ženevě Christopher Goodman, který stejně jako Knox musel Anglii opustit kvůli náboženským zákonům Marie Tudorovny.

Po dobu svého evropského exilu však Knox netrávil všechen čas pouze v Ženevě, několikrát cestoval např́ič Francií do přístavního městečka Dieppe, kde shromažd'oval informace o dění na Britských ostrovech. Na základě výpovědí jednotlivých uprchlíků se tak dozvídal o perzekucích a vzrůstající náboženské tyranii plynoucí ze strany královny Marie Tudorovny. ${ }^{25}$ Rozhodl se proto uspíšit své tažení namířené proti ženské nadvládě a již roku 1554 poslal anglickým učencům a znalcům Božích zákonů otevřený dopis, ve kterém je silně kritizoval za to, že se sklánějí před Jezábel z Anglie a poslouchají ji. ${ }^{26}$ Zašel až tak daleko, že připomínal výroky některých šlechticů, kteří dříve o Marii Tudorovně mluvili jako o bastardovi, ale nyní jí neváhali sloužit a označovat se za její věrné následovníky. ${ }^{27}$

Práce na Knoxově hlavním kritickém díle však trvala ještě několik let, v jejichž průběhu se Knox dokonce na čas vrátil do rodného Skotska, které tou dobou již ovládala profrancouzsky smýšlející regentka Marie de Guise, která v královském úřadu oficiálně zastupovala zájmy své dcery Marie Stuartovny. Britské královské trůny tak byly od roku 1554 osazeny ženskými panovnicemi, jejichž původ a směřování nemohly u Knoxe vyvolat sebemenší záchvěv náklonnosti. Marie Tudorovna byla katolička krví i manželstvím spřízněná se silně katolickým Španělskem. Marie de Guise byla též katolička a ke všemu ještě Francouzka, tzn. cizinka vládnoucí Skotsku a prosazující zájmy země, jejíž vojáci před lety uvrhli Knoxe do vězení a následně poslali na galeje. Právoplatná skotská královna Marie Stuartovna sice pocházela ze Skotska, ale již od svého dětství pobývala ve Francii, a proto mohla působit spíše jako Francouzka, než jako Skotka. Stejně jako její matka, i ona byla katoličkou, což v Knoxových očích ještě zhoršoval fakt, že byla zaslíbena francouzskému dauphinovi, čímž stejně jako Marie Tudorovna otevírala vlastní království vlivu cizích mocností a cizincům prosazujícím vlastní zájmy. Navzdory všem těmto faktům ale Knox pokračoval ve své kazatelské činnosti, v níž nejprve nevystupoval ani tak proti vládě žen královen, ale spíše proti skotské katolické církvi, jejíž roční příjem se v dané době pohyboval okolo 300000 liber, což přibližně sedmnáctkrát převyšovalo roční př́jmy skotského krále, které činily zhruba 17500 liber. ${ }^{28}$ Kritika ale nebyla katolickou církví přijata v dobrém a už roku 1556 byl John Knox, stejně jako před lety jeho mentor, obviněn z hereze a před upálením ho zachránila pouze milost vydaná skotskou regentkou Marií de Guise.

Co Marii de Guise vedlo k tomuto kroku, nemůžeme kvůli absenci pramenů doložit, ale je vysoce pravděpodobné, že si uvědomovala moc Knoxova vlivu na stále sílící protestantské hnutí, a proto nechtěla riskovat, že z Johna Knoxe udělá mučedníka, jehož jménem by se později zaštitovali nejrůznější vzbouřenci vystupující proti její vládě. Knox ale v jejím zákroku spatřoval znamení, že stále ještě není pozdě na to, aby ji přivedl na správnou cestu a přiměl ji tak k tomu, aby začala podporovat protestanty a následnou reformaci, na jejímž konci by se protestantismus stal skotským národním náboženstvím. $\mathrm{O}$ přínosu těchto kroků se ji snažil přesvědčit prostřednictvím dopisu, ve kterém též děkoval za záchranu svého života. Marie de Guise se ale s jeho argumenty a návrhy nijak

25 LAING, D. (eds.): The Works, 3, s. 251-253.

${ }_{26} 1 \mathrm{Kr} 18,4-18,13 ; 18,19$. Srov. NOVOTNÝ, Adolf: Biblický slovník. Praha 1992, s. 294.

27 LAING, D. (eds.): The Works, 3, s. 258-330.

28 MARLOW, M. (eds.): The Political Writings, s. 10. 
neztotožňovala, a proto i nadále vystupovala ve prospěch katolické církve, čímž si definitivně zajistila místo v Knoxem připravované práci kritizující vládu žen. Po krátké návštěvě Skotska se tak zklamaný Knox opět vrátil do švýcarské Ženevy. ${ }^{29}$

\section{První zatroubení polnic proti obludné nadvládě žen}

Počátkem roku 1558 vyšel traktát Knoxova prrítele Christophera Goodmana Jak by svrchovaní vládci měli naslouchat svým poddaným: A kdy je možno jim dle Božích zákonů odmítnout poslušnost a vzdorovat. ${ }^{30}$ Ten byl ale označen za natolik urážlivý, že otevření jakékoliv učené debaty na téma ženských práv a zastávání královského úřadu nepřicházelo v úvahu. Krátce poté vyšlo také Knoxovo nejznámější a nejkontroverznější dílo První zatroubení polnic proti obludné nadvládě žen. Jak již bylo řečeno, mělo se jednat o kritiku žen panovnic, která by celému světu ukázala, že se aktuální vývoj událostí na Britských ostrovech přičí Boží vůli a pokud se lidé chtějí vyhnout zaslouženému Božímu trestu, tak měli by se proti zmiňovaným královnám postavit. Knox se stejně jako Goodman nedržel nijak zpátky, když hned v úvodu své práce uvedl: Tento ostrov, běda, opovrhl a hrozivě zneužil nabízenou Boží milost a po hanebné zradě opustil Ježíše Krista a jeho evangelia kvưli Satanovi, a proto si následovníci této cesty oprávněně zaslouží, aby byli uvrženi do zmatku a poddanství v rukou cizinců. Přesto se obávám, že nedbalost těch, kteří jsou někdy zváni strážci, povede pouze ke zhoršení stávající situace. Vidíme, že se naše země stala kořistí cizích národů, slyšíme téct krev našich bratř́ v Kristu, kteří jsou krutě ponižováni monstrózním impériem ukrutné ženy, o které víme, že je příčinou veškerého utrpení, přesto však čas trávíme mlčením, jako kdyby se nás nic z toho netýkalo [...]. ${ }^{31}$

Ze samotné ukázky je patrných hned několik velmi úderných narážek na vládu stávajících královen, popř. královny. Knox tak již v úvodu své práce zmiňoval zmatek a poddanství v rukou cizinců, čímž dobovou realitu nijak výrazně nepřikrášloval. V době, kdy Knox pracoval na svém Prvním zatroubení, byly Anglie a Skotsko již zmiňovanými cizinci vtaženy do válečného konfliktu probíhajícího mezi Francií a Španělskem. K tomuto zapojení do války došlo kvůli již zmiňovaným sňatkům uzavřeným jak mezi anglickou královnou Marií Tudorovnou a španělským králem Filipem II., tak mezi skotskou královnou Marií Stuartovnou a francouzským dauphinem Františkem. Dalo se proto pochopit, že veškeré finanční výdaje, ztráty na životech a utrpení kladl Knox za vinu právě královnám, které své země uvrhly do zmatku jen kvůli tomu, že se provdaly za cizince. Dále zde můžeme vidět opětovnou kritiku pokryteckých šlechticů, kteří se navzdory svému původnímu přesvědčení neváhali přidat na stranu Marie Tudorovny, popř. odkazy na utrpení protestantů, kteří byli perzekuování na základě obnovených kacířských zákonů.

\footnotetext{
29 HEALEY, Robert: Waiting for Deborah : John Knox and Four Rling Queens. The Sixteenth Century Journal 25, 1994, č. 2, s. 374-375.

30 GOODMAN, Christopher: How Superior Powers Ought To Be Obeyed By Their Subjects : And Wherein They May Lawfully By God's Word Be Disobeyed And Resisted. Geneva 1558.

31 That isle, alas, for the contempt and horrible abuse of God's mercies offered, and for the shameful revolting to Satan from Christ Jesus and from his Gospel ones professed, doth justly merit to be left in the hands of their own counsel and so to come to confusion and bondage of strangers. But yet I fear that this universal negligence of such as sometimes were esteemed watchmen shall rather aggravate our former ingratitude than excuse this our universal and ungodly silence in so weighty a matter. We see our country set forth for a prey to foreign nations; we hear the blood of our brethren, the members of Christ Jesus, most cruelly to be shed; and the monstrous empire of a cruel woman we know to be only occasion of these miseries; and yet with silence we pass the time as thought the matter did nothing appertain to us. MARLOW, M. (eds.): The Political Writings, s. 37-38.
} 
Knox nejspíše počítal s tím, že bude za svou práci v budoucnu perzekuován, ale k samotnému vydání svého Prvního zatroubení přistupoval tak, že [...] jsme v naší bídné době povinni napomenout svět a jeho tyrany v jejich ukvapené destrukci, abychom je ujistili a zakřičeli na ně, at' už poslouchají nebo ne, že krev světců, kterou neustále prolévají, nadále volá a prahne po pomstě v prítomnosti Boží. ${ }^{32}$ Snažil se tak sám sebe vykreslit jako neutrálního pozorovatele a šiřitele Boží pravdy, jehož cílem, popř. cílem celého díla nebyla pomsta a otevřené vystoupení proti tyranským královnám, ale povinnost upozornit svět na to, že se s ním děje něco špatného. Něco, co je třeba změnit, aby se tak předešlo Boží pomstě. Vedle obvinění a vysvětlení príičin vzniku svého díla ale Knox představil i své úvahy o trestech a perzekuci, které ho měly za tento politický traktát postihnout. Samotný styl, kterým tato fakta ve svém díle prezentoval, ho však mohl v budoucnu velmi dobře ochránit, protože v př́padě praktického naplnění jednotlivých postihů by kritizované královny daly Knoxovi pouze za pravdu. Knox ve své práci hlásal: Budu označen za hlupáka, podivína, zlomyslného člověka a rozsévače protistátních nálad. A jednoho dne budu úplnou náhodou obviněn ze zrady. ${ }^{33}$

Zmínky o velezradě jsou v tomto případě o to zajímavější a trefnější, že si sám Knox musel být vědom toho, že se budoucí obvinění budou nejspíše zakládat bud' na kacířství, nebo vlastizradě, přičemž z kacířství byl ve Skotsku již obviněn. Po odchodu ze země byl jeho proces obnoven a Knox tak byl v nepř́tomnosti odsouzen k trestu smrti upálením. ${ }^{34}$ Na základě kontaktů s řadou anglických exulantů mu muselo být jasné, že bude v př́padě návratu do země obviněn $\mathrm{z}$ velezrady. V praxi by $\mathrm{k}$ takovému procesu a odsouzení určitě došlo, protože Marie Tudorovna již během roku 1555 vydala Druhý zákon o velezradě 35 a Zákon proti zrádným slovům, ${ }^{36}$ přičemž oba velmi podrobně vyjmenovávaly provinění, kterých se ve svém díle John Knox dopouštěl. Ironií je, že i když bylo z Knoxova Prvního zatroubení citováno opravdu velmi málo, již zmíněné pasáže by stačily k jeho odsouzení, protože Druhý zákon o velezradě měl perzekuovat kohokoliv, kdo by šíril pomluvy a hanebné lži o královně Marii, o jejím zákonném manželovi, jejich nárocích na vládu nad Anglií, fyzickém i psychickém stavu jejich možných potomků a dědiců atd. ${ }^{37}$ Zákon proti zrádným slovưm byl v podstatě velmi podobný, a v některých případech se oba zákony dokonce shodovaly, ale v př́padě tohoto zákona bylo označeno za nezákonné i to, když se někdo tajně scházel kvůli ceremoniím spojeným s protestantskou vírou, když ve svých modlitbách přál zlé věci královně Marii atd. Každý, kdo se podobným způsobem provinil proti těmto zákonům, měl být okamžitě uvězněn a souzen jako vlastizrádce. ${ }^{38}$ Oba zákony navíc poskytovaly dostatek prostoru k tomu, aby jejich prostřednictvím mohlo dojít k obvinění a odsouzení nepohodlných osob. John Knox však ve své kritice a argumentaci pokračoval navzdory možnému riziku.

\footnotetext{
32 We in this our miserable age are bound to admonish the world and the tyrants thereof of their sudden destruction, to assure them, and to cry unto them, whether they list to hear or not, that the blood of the saints, which by them is shed, continually cries and craves vengeance in the presence of the Lord of hosts. Tamtéž, s. 38.

33 I shall be called foolish, curious, despiteful, and a sower of sedition; and one day, perchance, although now I be nameless, I may be attainted of treason. Tamtéž, s. 41.

34 HEALEY, R.: Waiting for Deborah, s. 375.

35 TANNER, J. (eds.): Tudor Constitutional Documents, s. 408-411.

36 Tamtéž, s. 407-408.

37 Tamtéž, s. 408-411.

38 Tamtéž, s. 407-408.
} 
V samotném díle bylo možné jeho argumenty rozdělit hned do několika kategorií, jejichž určujícím faktorem byl použitý zdroj. Největší množství argumentů se opíralo o Knoxovu znalost Písma a biblických príběhů, dále zde bylo mnoho narážek na př́rodní zákony a obecně známé předsudky namířené proti ženským charakterovým rysům a vlastnostem. Ženy tak byly vykreslovány jako fyzicky i psychicky velmi slabé, náchylné ke hříchu, nenasytné, pomstychtivé a chamtivé bytosti, kterým by právě pro jejich charakterové vady měla být vláda nad muži odepřena. ${ }^{39}$ Poslední, ale neméně důležité byly odkazy na díla dalších autorů, jejichž názory na ženy se shodovaly s těmi Knoxovými. V př́ípadě odkazů na Bibli Knox užíval především příběhů, ve kterých figurovaly tyranky, uzurpátorky trůnu a proradné ženy vystupující proti Bohu. Odkazoval tak na prvotní hřích, ke kterému Adama navedla Eva, čímž zapříčinila nejen vyhnání lidstva z ráje, ${ }^{40}$ ale také trest $\mathrm{v}$ podobě každodenní dřiny a práce, porodní bolesti seslané na všechny ženy a také ženskou podřízenost mužské autoritě, aby již nikdy nepodlehla pokušení a neinklinovala $\mathrm{k}$ dalším hříchům. ${ }^{41} \mathrm{~K}$ nejfrekventovanějším jménům ale nepatřila Eva, nýbrž Jezábel ${ }^{42}$ a její dcera Atalja, ${ }^{43}$ které byly symbolem starozákonních královen, jež svou tyranskou vládou a násilím podporovaly staré pohanské modly a pro svou touhu po moci neváhaly odstranit nejednoho muže.

Argumentace založená na výkladu prírodních zákonů byla svým zpo̊sobem velmi blízká výkladu Písma, což bylo pro 16. století stále naprosto typické. Knox zde tvrdil, že by mohl vyprávět príběhy o ženách, které zemřely pro potěšení, některé se zahubily díky své netrpělivosti, jiné spálila jejich nadměrná touha, pro jejíž uhašení byly ochotny zradit svou zemi a město cizincưm, některé natolik toužily po nadvládě, že zavraždily děti svých vlastních synů. Ano, některé dokonce krutě zavraždily vlastního manžela a děti. ${ }^{44}$ Čímž opět odkazoval jak na sňatky Marie Tudorovny i Marie Stuartovny, tak na jim přisuzovaná jména Jezábel a Atalji, kdy právě Atalja toužila po vládě natolik, že pro ni neváhala zavraždit všechny mužské dědice a př́buzné. Jezábel byla ve Starém Zákoně matkou Atalji, a proto se celé symbolické spojení dalo vztáhnout také na Marii de Guise a Marii Stuartovnu. Autor však pokračoval výroky: Ženský druh je nedůvěřivý a měkký nebo poddajný. Nedůvěrivý je proto, že není schopen uvažovat moudře a pochopit věci, které slyšel a viděl; poddajný je proto, že je lehké si jej podř́dit. ${ }^{45}$ Ženský druh je zbrklý a hloupý, jejich lakota je stejně neukojitelná, jako jáma pekelná. ${ }^{46}$ Ani tím však Knoxova argumentace nekončila. Knoxovy zkušenosti pramenily především z jeho kazatelské činnosti, a proto i do svých spisů vkládal prŕiklady, které mohl lehce pochopit i prostý člověk, kterému by Knoxova práce mohla

\footnotetext{
MARLOW, M. (eds.): The Political Writings, s. 45.

40 Gn 2,21-2,22; Gn 3,16; Gn 4,1-4,25; Gn 5,1-5,5.

41 Tाm 2,13-2,15.

$42 \quad 1 \mathrm{Kr} 18,4-18,13 ; 1 \mathrm{Kr} 18,19$.

$432 \mathrm{Kr} 8,18-8,26 ; 2$ Pa 21,6. Srov. NOVOTNÝ, A.: Biblický slovník, s. 294.

44 I might adduce histories proving some women to have died for sudden joy, some for unpatience to have murdered themselves; some to have burned with such inordinate lust that, for the quenching of the same, they have betrayed to strangers their country and city; and some to have been so desirous of dominion that, for the obtaining of the same, they have murdered the children of their own sons. Yea, and some have killed with cruelty their own husbands and children. MARLOW, M. (eds.): The Political Writings, s. 45.

45 Womankind is imprudent and soft or flexible. Imprudent because she cannot consider with wisdom and reason the things which she heareth and seeth; and soft she is because she is easily bowed. Tamtéž, s. 53.

${ }_{46}$ Womankind [...] is rash and foolhardy, and their covetousness is like the gulf of hell, that is, insatiable. Tamtéž, s. 54 .
} 
být předčítána během tajných setkání anglických protestantů. Knox proto dále upozorňoval na fakt, že v rámci aktu stvoření byl prvním člověkem Adam, z jehož žebra byla teprve časem stvořena Eva. Z tohoto důvodu je patrné, že Eva byla zrozena z Adama a pro Adama, a proto mu byla již od prvních dní podřízena. Adam byl tedy tím, kdo měl již od počátku světa vyšší autoritu a kdo měl ženu v jejím konání řídit a usměrňovat. Tento Boží záměr byl ještě posílen spácháním prvního hříchu, za jehož uskutečnění opět mohla Eva. Byla to přece ona, kdo Adama přiměl utrhnout jablko, a tak už první prípad uplatnění ženské autority nad mužem skončil pohromou, po které bylo lidstvo vyhnáno z ráje a Eva byla náležitě potrestána porodními bolestmi a svou podř́zeností Adamovi. ${ }^{47}$

Role muže a vládce byla z biologického hlediska spojována s činností hlavy, která $\mathrm{v}$ rámci lidského těla řídí všechny končetiny a orgány. Ve chvíli, kdy na královský trůn usedla žena, došlo k narušení řádu a rovnováhy. Úlohu hlavy totiž nyní nezastával muž, a proto vzniklo něco Bohu i přírodě zcela odporného, jakýsi kř́iženec, nestvůra, proměněnec, který na místo hlavy kladl jiný orgán nebo končetinu. Ano, právě tak John Knox ve svém Prvním zatroubení popisoval důsledky ženského uzurpování královské autority, kvůli nimž odvěký řád vystřídal chaos, protože nebylo možné, aby například noha zvládala činnost hlavy a hlava úlohu svěřenou nohám. Navíc po velmi obsáhlém výčtu negativních vlastností, kterými disponovala každá žena, bylo v podstatě nemožné, aby se vlády nad zemí ujala královna schopná zastávat úlohu, která byla dříve svěřována právě mužům. ${ }^{48}$

Těmito názory ale Knox nijak nevybočoval z dobové normy, protože stejně o ženských charakterových vlastnostech, schopnostech a dovednostech smýšlela většina tehdejších mužů i žen. Obecně bylo považováno za nemožné, aby žena vládla stejně schopně jako muž. Navzdory těmto všeobecným předsudkům ale nikdo doposud takto otevřeně a hrubě nekritizoval nejvýše postavené ženy z urozených královských rodů. John Knox tak byl spolu se svým přítelem Christopherem Goodmanem prvním, kdo ve své práci dokonce popisoval okolnosti, za kterých se poddaný může postavit tyranské vládě takových panovnic, jejichž kralování je v rozporu s Božími i přírodními zákony. Svými činy, tyranskými zákony a perzekucí protestantů stejně ukázaly, že nejsou hodny postu královny. Jak by také mohly, když se provdaly za cizince a své země tak vehnaly do válek, které ani nebyly v jejich zájmu. Ne, pro Johna Knoxe ani Marie Tudorovna, ani Marie de Guise či Marie Stuartovna nesplňovaly kritéria, za kterých by byl ochoten akceptovat jejich vládu. Právě naopak, svými činy si u Knoxe vysloužily leda pohrdání a obvinění ze zrady vlastních království i poddaných.

Již několikrát zmíněné sňatky s cizími vládci byly pro Knoxe opravdu důležitým bodem, který opakovaně kritizoval prostřednictvím výkladu starozákonního příběhu o dcerách Zelophehad: Je tu jedna věc, kterou je třeba zmínit a dodržet v př́padě zákona vztahujícího se na dědictví dcer Zelophehad. Bylo jim zapovězeno, aby se provdaly za někoho, kdo nepocházel z jejich vlastního kmene. ${ }^{49}$ Zajímavéje to, že ochránci a patroni práv našich dam nevzali tento zákon $v$ potaz predtím, než poradili zaslepené princezně a nedobrým šlechticům, aby zradili staré svobody a předali moc do rukou cizinců. Anglie byla pro uspokojení nesmírného chtíče toho ukrutného monstra Marie (pro krvavou tyranii nehodné označení žena) zrazena, běda, ve prospěch hrdého Španěla. A Skotsko, pro vlnu šílenství a hlouposti

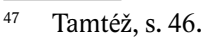

48 Tamtéž, s. 56.

49 One thing is yet to be noted and observed in the law made concerning the inheritance of the daughters of Zelophead, to wit, that it was forbidden unto them to marry without their own tribe [...]. Tamtéž, s. 71 .
} 
svých správců a pro praktiky dravé dámy, rezignovalo obdobně pod záštitou manželství pod nadvládu Francie. ${ }^{50}$ Starozákonní příběh měl poukázat na aktuální situaci na půdě Britských ostrovů, kde Anglie i Skotsko ztrácely svou nezávislost a svobodu právě kvůli sňatkům, které je dostaly pod kontrolu dobových mocností Francie a Španělska. Kritika v tomto př́padě ale již nebyla namířena pouze proti ženám, ale také proti jejich rádcům a ochráncům, kteří jim v popsaných krocích nezabránili, a dokonce je v nich možná podporovali. Knoxova silná antipatie ke všem zmíněným byla velmi dobře patrná už ze jmen a vlastností, které jim v citovaném textu přisuzoval: zaslepená princezna, nedobří šlechtici, zrada starých svobod, ukrutné monstrum Marie, nehodna označení žena, hrdý Španěl, hloupí správci, dravá dáma, nadvláda Francie. Text je tak v podstatě prostoupen negativním popisem jak jednotlivých královen, tak jejich manželů a rádců.

Muži, kteří podle Knoxe zradili protestantskou víru, Boha a pravý řád věcí, si ale také zasloužili odpovídající trest. Knox svůj názor na ně popsal takto: Proto je soudím nejen jako služebníky žen, ale též jako služebníky samotného Satana, jako služebníky nepravosti [...] d'ábel, vládce tohoto světa, vládne těmto tyranům. ${ }^{51}$ Taková obvinění byla samozřejmě velmi vážná a nebrala se na lehkou váhu. Knox ale těmto hř́šníkům chtěl ukázat cestu k možnému vykoupení, a proto ve svém Prvním zatroubení uvedl: Musí odmítnout práci $v$ rolích jejích správců, protože ona (královna, pozn. aut.) zrazuje Boha a staví se proti němu. ${ }^{52}$ A dále, musí hloubat nad tím, jak přemoci její nepřměrenou pýchu a tyranii [...] Totéž je povinností šlechty a majetných, skrze jejichž zaslepenost byla žena povýšena. ${ }^{53}$ Tato pomyslná cesta k vykoupení se ale až př́liš podobala navádění k rebelii a zradě královny. Vždyt Knox muže otevřeně nabádal k tomu, aby pro královnu již dále nepracovali a začali raději spřádat plány vedoucí k porážce její pýchy a tyranie. John Knox se tímto krokem výrazně odlišil od ostatních dobových reformátorů, protože i když se např́íklad Jan Kalvín a Heinrich Bullinger v Ženevě vyjadřovali proti ženským nárokům na královský titul, př́íčilo se jim otevřené nabádání ke vzpouře proti královské autoritě. Král podle jejich učení mohl být špatný, ale ani to poddaným nedávalo právo na to, aby proti svému vládci povstali. To ale nebyl Knoxův prrípad, nebot' jak je z jeho práce patrné, na cestě za dosažením svých cílů se nebránil ani násilné reformaci a rebelii proti korunovaným panovnicím. ${ }^{54}$

Knox se totiž cítil být povolán k prosazování Boží pravdy, o které si myslel, že ji správně chápe pouze on. V podstatě se tak ztotožňoval s úlohou proroka, který měl varovat anglický a skotský lid před hrůzami, které přinesla obludná nadvláda žen a jež může zažehnat jedině on. ${ }^{55}$ Ve své práci předpověděl příchod Božích trestů, které již brzy učiní přítrž panování bezbožných žen, a právě proto tak otevřeně varoval všechny jejich služebníky,

\footnotetext{
50 Wonder it is that the advocates and patrons of the right of our ladies did not consider and ponder this law before that they counseled the blind princes and unworthy nobles of their countries to betray the liberties thereof into the hands of strangers. England, for satisfying of the inordinate appetites of that cruel monster Mary (unworthy by reason of her bloody tyranny of the name of a woman), betrayed, alas, to the proud Spaniard; and Scotland, by the rash madness of foolish governors and by the practices of a crafty dame, designed likewise, under title of marriage, into the power of France. Tamtéž, s. 71.

51 Wherefore I judge them not only subjects to women, but slaves to Satan and servants of iniquity [...] Then it resteth that the devil, the prince of this world, doth reign over such tyrants. Tamtéž, s. 60 .

52 They mustr efuse to be her offcers, because she is a tratoress and rebel against God. Tamtéž, s. 74.

53 And finally, they must study to repress her inordinate pride and tyranny to the uttermost of their power. Tamtéž, s. 74-75.

54 LAING, D. (eds.): The Works, 3, s. 222.

55 KYLE, Richard: John Knox and Apocalyptic Thought. The Sixteenth Century Journal 15, 1984, č. 4, s. 449-450.
} 
aby je tak před příchodem již zmiňovaného trestu vrátil na správnou cestu, kterou v jeho případě symbolizovala protestantská víra a vláda mužského panovníka. Zmínil také, že královny: Jeho (myšleno Boží, pozn. aut.) pomstě nemohou uniknout, stejně tak, jako jí neunikl Kain, Jidáš, Herodes, Julianus zvaný Apostata, Jezábel a Atalja. ${ }^{56}$ Už po několikáté je tak přirovnal ke zrádcům a odpadlíkům, kteří se jak v rámci biblických př́běhů, tak v rámci lidských dějin odklonili od Boha a dopustili se tak velkých prohřešků. Motiv Boží pomsty, popř. trestu prostupoval celým Knoxovým dílem. Vždyt' už to, že muži byli podřízeni ženám, připomínalo opak trestu, kterým Bůh stihl Evu za protivení se jeho vůli. Proč by tedy dobové dění na půdě Britských ostrovů nemohlo být Knoxem interpretováno jako Boží odplata namířená proti mužům, kteří nedbali Božích zákonů a dovolili nejen to, aby se žena zmocnila královského úřadu, ale i to aby uzavřela sňatek s cizincem? Vždyt do nástupu obludné nadvlády žen byly Anglie a Skotsko v Knoxových očích země otevřené myšlence protestantismu, a tudíž i Boží vůli. Po smrti Edwarda VI. byla tato cesta přerušena nástupem Marie Tudorovny a Marie de Guise. A protože ani anglická, ani skotská šlechta nezabránila jejich nástupu na trůn, popř. pozdějšímu prosazení zákonů namířených proti protestantům a umožňujících perzekuci a pronásledování poddaných, jen si zasloužila léta strávená pod jejich krutovládou. Obě země si ale kromě ženské nadvlády, náboženské perzekuce, pronásledování a válek zapříčiněných cizími mocnostmi již vytrpěly dost, a právě proto se Knox rozhodl o všech těchto hrůzách informovat svět prostřednictvím svého Prvního zatroubení.

Bůh tak podle něj proklel Jezábel z Anglie spolu se smrtícími a odpornými papeženci, neschvaluje a není pyšný na to, že triumfovala nejen proti Wyattovi, ale též proti všem ostatním, kteří proti ní vystoupili, popř. kritizovali její jednání. Necht' si však uvědomí, že nezískala převahu nad Bohem, jehož trün se nachází výše, než kam kdy její rohy mohly dosáhnout. A necht též vezmou v potaz, že její vláda započala spolu se žněmi nespravedlnosti velmi nedospěle a nezrale. Ne, bylo to tak nezkušené, tak utajované, tak zaobalené, tak skryté a pokrytecké, že někteří muži - dokonce i služebníci Boží-mysleli, že není nemožné, aby se $z$ vlků stala jehňata a že se zmije může zbavit svých přirozených jedů [...]. ${ }^{57}$ Muži $i$ ženy, učení i neučení, bohatí i muži z prostých vrstev, letití otcové $i$ citlivé slečny, a konečně kosti mrtvých žen a mužů okusili její tyranii. ${ }^{58}$ Nejen krev otce Latimera, mírného muže Božího, biskup a Canterbury, učeného a diskrétního Ridleyho, nevinné lady Jane Dudleyové a mnoha zbožných a ctihodných kazatelư, kteři nesmí být zapomenuti [...]. ${ }^{59}$

V závěru svého spisu Knox předložil jak finální výčet svých obvinění, tak jména dle jeho názoru nejváženějších obětí, za jejichž smrt opět nesla vinu právě Marie Tudorovna.

\footnotetext{
$56 \quad[. .$.$] whose vengeance cannot escape - as did Cain, Judas, Herod, Julian called Apostate, yea, Jezebel and Atha-$ liah. MARLOW, M. (eds.): The Political Writings, s. 63.

57 Cursed Jezebel of England, with the pestilent and detestable generation of papists, make no little brag and boast that they have triumphed not only against Wyatt, but also against all such as have enterprised anything against them or their proceedings. But let her and them consider that yet they have not prevailed against God; his throne is more high than the length of their horns be able to reach. And let them further consider that in the beginning of this their bloody reign the harvest of their iniquity was not comen to full maturity and rupeness. No, it was so green, so secret I mean, so covered, and so hid with hypocrisy that some men - even the servants of God-thought it not impossible but that wolves might be changed into lambs, and also that the viper might remove her natural venom. Tamtéž, s. 77.

58 For man and woman, learned and unlearned, nobles and men of baser sort, aged fathers and tender damsels, and finally the bones of the dead, as well women as men, have tasted of their tyranny. Tamtéž, s. 77 .

59 So that now not only the blood of father Latimer, of the mild man of God, the bishop of Canterbury, of learned and discrete Ridley, of innocent Lady Jane Dudley, and many godly and worthy preachers that cannot be forgotten [...]. Tamtéž: The Political Writings, s. 77.
} 
Jmenoval Sira Thomase Wyatta, ${ }^{60}$ který se roku 1554 zúčastnil povstání proti Marii Tudorovně, jehož příčinou bylo její rozhodnutí, že se provdá za španělského krále Filipa II. Vzbouřenci chtěli Marii Tudorovnu sesadit a vládu nad Anglií předat její nevlastní sestře Alžbětě. ${ }^{61}$ Povstání ale ztroskotalo a vzbouřenci byli uvězněni a řada z nich i popravena, přičemž stejný trest po nějaký čas hrozil i princezně Alžbětě, která by v prrípadě úspěchu zaujala post anglické královny. Hugh Latimer a Nicholas Ridley naproti tomu představovali církevní oběti Mariiny krutovlády. Latimer i Ridley byli protestanti, a proto byli obviněni z kacířství, přičemž Nicholas Ridley ještě ke všemu otevřeně podporoval Mariinu konkurentku v bojích o anglický trůn Jane Greyovou. Ta byla pravnučkou Jindřicha VII., sestřenicí Edwarda VI., a dokonce dědičkou, které Edward VI. odkázal anglický trůn ve své závěti. Marie Tudorovna ji však nechala již v únoru 1554 popravit i s jejím manželem, čímž jednoho po druhém odstranila všechny své konkurenty v mocenském boji o vládu nad anglickým královstvím. A jelikož všichni jmenovaní skončili bud' na popravišti, nebo na hranici, není divu, že Knoxovi posloužili jako dokonalé př́́klady Mariiny tyranie a hrůzovlády.

\section{Neočekávané důsledky Knoxova Prvního zatroubení}

Když ale Knoxovo První zatroubení proti obludné nadvládě žen roku 1558 opustilo Ženevskou tiskárnu Johna Crespina, nesetkalo se s pochopením a př́znivým ohlasem ani mezi reformátory, ani mezi Knoxovými spolupracovníky a přáteli. Naopak se na Johna Knoxe snesla vlna kritiky kvůli otevřenosti a radikálnosti jeho názorů, jejichž šíření mohlo zpo̊sobit řadu povstání např́íc Britskými ostrovy. ${ }^{62}$ A s tím nechtěl mít nikdo ze ženevských reformátorů nic společného. Další problém spočíval v tom, že na podzim roku 1558 zemřela Knoxem tolik proklínaná královna Marie Tudorovna, na jejíž místo nastoupila její nevlastní sestra Alžběta. Té Knoxovo První zatroubení nástup na anglický trůn nijak neusnadnilo a logicky u ní vzbudilo velký odpor.

Královna Alžběta totiž měla v prvních letech své vlády řadu problémů s uznáním dědických nároků na anglický trůn. Její matka, Anna Boleynová, ${ }^{63}$ byla totiž Jindřichem VIII. odsouzena k trestu smrti, a Alžběta byla dokonce označena za pancharta, který podle katolického církevního práva nemohl uplatňovat dědičné nároky na královský titul. ${ }^{64}$ Stejně ale mohlo být nahlíženo i na Marii Tudorovnu, kterou Jindřich VIII. ve svých zákonech o nástupnictví vnímal úplně stejně jako Alžbětu. Marie Tudorovna ale bojovala za obnovení anglického katolicismu a její matka byla v očích katolické církve právoplatnou ženou Jindřicha VIII. V jejím př́ípadě tak nebyl takový problém v uznání dědičných nároků na

60 O Thomasu Wyattovi a jeho povstání proti Marii I. Tudorovně in: FLETCHER, Anthony: Tudor Rebellions. London 2004; LOADES, David: Two Tudor Conspiracies. Cambridge 1965.

${ }^{61} \mathrm{Z}$ nejvýznamnějších prací věnovaných královně Alžbětě I. z rodu Tudorovců zmiňme např. LOADES, David: Elizabeth I. London 2006; REX, Richard: Elizabeth I. Stroud 2003; STARKEY, David: Elizabeth: The Struggle for the Throne. New York 2001; HAIGH, Christopher: Elizabeth I. London 2000; MacCAFFREY, Wallace: Elizabeth I. London 1993; NEALE, John: Queen Elizabeth I. Chicago 1992; SOMERSET, Anne: Elizabeth I. New York 1991; ERICKSON, Carolly: The First Elizabeth. New York 1983; JOHNSON, Paul: Elizabeth I. New York 1974.

62 LAING, D. (eds.): The Works, 4, s. 351.

63 Anně Boleynové se ve svých výzkumech věnoval např. BERNARD, George: Anne Boleyn : Fatal Attractions. New Haven 2010; IVES, Eric: The Life and Death of Anne Boleyn. Oxford 2004; WARNICKE, Retha: The Rise and Fall of Anne Boleyn. Cambridge 1989.

64 TANNER, J. (eds.): Tudor Constitutional Documents, s. 382-388, 389-395, 397-400. 
trůn jak ze strany papeže, tak ze strany dalších evropských katolických vládců. Alžběta ale byla protestantka, a tak se srovnatelným druhem zahraniční podpory nemohla počítat. Katolickou Evropou byla jako právoplatná nástupkyně Marie Tudorovny vnímána skotská a francouzská královna Marie Stuartovna.

Knoxův záměr podkopat autoritu vládnoucích katolických královen mohl kvůli špatnému načasování způsobit pravý opak. Namísto Marie Tudorovny a Marie de Guise tak v danou chvíli První zatroubení působilo problémy jediné královně, která hájila zájmy britských protestantů. John Knox sice nemohl vědět, že Marie Tudorovna zemře, ale i tak se jeho dílo záhy otočilo proti němu. Špatné načasování bylo o to nebezpečnější, že právě v roce 1558 francouzská armáda dobyla přístavní město Calais, čímž Anglii zcela odřízla od spojení s kontinentální Evropou a riziko možného napadení anglických břehů nebezpečně vzrostlo. ${ }^{65}$ Ve stejné době se Marie Stuartovna provdala za francouzského dauphina Františka, čímž se aliance mezi Francií a Skotskem ještě více utužila. ${ }^{66}$ Kvůli opětovnému anglickému návratu k protestantské víře došlo také ke zhoršení vztahů s jejím posledním spojencem Španělskem. ${ }^{67}$ Situace se tak zdála být kritická i bez Johna Knoxe a jeho práce podkopávající ženská práva na vládu, popř. dokonce podněcující poddané a šlechtu k povstání. Pro Alžbětu bylo srovnání s ostatními panovnicemi o to horší, že kromě svého původu a dědičných práv musela bojovat i s tím, že neměla manžela, jehož autorita by mohla některé z problémů alespoň částečně zastínit. Skotská regentka Marie de Guise byla vdova, která pouze zastupovala svou dceru po dobu její nepř́ítomnosti, přičemž Marie Stuartovna byla právoplatnou skotskou královnou s nepopiratelným manželským původem, a dokonce i s manželem, u kterého se v budoucnu dal předpokládat zisk francouzské koruny.

Navzdory problémům, které vydáním svého díla způsobil, se John Knox toužil vrátit domů. Předpokládal, že po smrti Marie Tudorovny skončilo období pronásledování a perzekucí namířených proti protestantům, a nejspíše i doufal v to, že královnou Alžbětou nebude obviněn z vlastizrady. Na přelomu let 1558-1559 tak začal psát omluvné dopisy jak královně Alžbětě, tak jejímu nejbližšímu poradci Williamu Cecilovi. Ve svých dopisech se snažil uvést na pravou míru příčiny svého jednání a zajistit si tak bezpečný průjezd Anglií, kde chtěl navštívit své přátele z let, kdy sloužil Edwardovi VI. V jednom z těchto dopisů například uvedl: Nemohu poprít práci na knize namířené proti usurpování autorit a nespravedlivé vládě žen, doposud jsem neodvolal nebo nevzal zpět žádný z hlavních bodủ a tvrzení, což bude platit, dokud pravda a skutečnost nezjeví nová fakta. ${ }^{68}$ Namísto pokory a omluv tak Knox hodlal stát za svými názory až do chvíle, kdy si nová královna svými činy zaslouží přehodnocení jeho názorů. Každé jednání však přináší důsledky, a proto byly všechny žádosti o průjezd Anglií zakázány. Knox tehdy v jednom ze svých dopisů poznamenal: Mé První zatroubení ode mne odehnalo všechny mé anglické prátele. ${ }^{69}$

Nezbylo mu tedy nic jiného než př́mý návrat do rodného Skotska, kde nad ním však i nadále visel pomyslný Damoklův meč v podobě dřívějších obvinění z hereze. Roky po

\footnotetext{
65 SUTTON, Dana (eds.): Annales Rerum Anglicarum et Hibernicarum Regnante Elizabetha. California 2001, s. 30 .

66 Tamtéž, s. 46-47.

67 Tamtéž, s. 30.

68 I can not deny the writting of a book against the usurped Authority and unjust Regiment of Women; neither yet am I minded to retract or call back any principall point or proposition of the same, till truth and verity do futher appeir. LAING, D. (eds.): The Works, 4, s. 353.

69 My First Blast hath blown from me all my friends in England. LAING, D. (eds.): The Works, 4, s. 353.
} 
vydání jeho Prvního zatroubení byly o to horší, že nepřišel pouze o kontakt se svými anglickými přáteli, ale také mohl sledovat, jak jej kritizují a opouštějí další reformátoři, kteří si nikterak nechtěli znepřátelit britské královny. Jako příklad můžeme uvést Jana Kalvína, který k anglickému královskému dvoru zaslal svůj omluvný list, ve kterém se snažil očistit z jakékoliv spoluúčasti na vzniku Knoxova díla. V dopise uvedl: Před dvěma lety se mne během soukromého rozhovoru John Knox zeptal, co si myslím o vládě žen. Upř́mně jsem mu odpověděl, že stejně jako odchýlení se od prvotních a správných zákonů prírody, jako tomu bylo v př́padě otroctví, tak $i$ v tomto prípadě se jedná o důsledek a trest za úpadek mužů; občas se však objeví žena, která je obdařena jednotlivými vlastnostmi, které v ní doslova zazárí a vyzdvihnou ji díky Boží vůli. Bůh tak rozhodl bud' proto, aby potrestal zkaženost mužů, nebo aby zvěstoval svou vlastní slávu. Za príklad jsem si vybral Chuldu a Deboru a poukázal na to, že Bůh skrze Izaiáše marně nesliboval, že královny mohou být opatřujícími matkami církve, přčemž z jejich privilegií je patrné, že jsou zcela rozdílné oproti ženám vosobním životě. Dlouho jsem dospíval k názoru, že na základě zvyku, s veřejným souhlasem a dlouhou př́pravou mohou říším a knížectvím vládnout ženy skrze svá dědičná práva [...]..$^{70}$ V Kalvínově omluvném listu se tak dá nalézt řada podobností s argumenty, které ve své práci užíval John Knox. Na druhou stranu ale Kalvín též nabídl několik podnětů, na které později mohli navázat obhájci ženského práva na vládu nad svěřeným královstvím. Kalvínovy odkazy na Chuldu, ${ }^{71}$ Deboru $^{72}$ a Izaiáše ${ }^{73}$ v podstatě poukázaly na slabiny Knoxova díla, které zcela postrádalo pozitivní příklady ženských autorit. Kalvín zde kladl důraz na proroky, tzn. z hlediska Starého zákona na osoby, ke kterým byla chována velká úcta a k nimž patřily i ženy, jako např́iklad Chulda a Debora, k nimž izraelští králové posílali svá poselstva s prosbou o radu. Nebylo náhodou, že se právě předobraz Debory a Chuldy stal v pozdějších letech jakýmsi ideálem ženy panovnice.

Tomuto vzoru se podle Kalvína nejvíce přiblížila právě anglická královna Alžběta, ale ani ona zcela nenaplnila Knoxova očekávání. Ano, Alžběta byla protestantská královna, která Anglii navrátila její dřivější víru, ale zároveň byla tolerantní vůči anglickým katolíkům. ${ }^{74}$ Svým tolerantním prrístupem předešla rozmachu náboženských nepokojů, které mohly přerůst až v občanskou válku, jako například ve Francii. Knoxovo smýšlení ale bylo natolik striktní a radikální, že neschvalovalo žádné podobné kompromisy. John Knox byl proto nucen komunikovat s královniným rádcem Williamem Cecilem, se kterým udržoval kontakt prostřednictvím korespondence, jejímž cílem bylo zajištění anglo-skotské protestantské spolupráce za účelem zpřetrhání vazeb mezi Francií a Skotskem a prosazení protestantské víry jako nového skotského státního náboženství ${ }^{75}$

\footnotetext{
$70 \quad$ Two years ago John Knox aske dme, in a private conversation, what I thought about the Government of Women. I candidly replied, that as it was to be ranked, no less than slavery, among the punishments consequent upon the fall of man; but that there were occasionally women so endowed, that the singular good qualities which shone forth in them made it evident that they were raised up by Divine authority; either that God designed by such examples to condemn the iniciativyty of men, or for the better setting forth his own glory. I brought forward Huldah and Deborah; and added, that God did not vainly promise by the mouth of Isaiah, that Queens should bet he nursing mothers of the Church; by which prerogative $i$ tis very evident that they are distinguished from females in private life. I came at length to this conclusion, that since, both by custom, and public consent, and long practice, it has been established, that realms and principalities may descend to females by hereditary right [...]. LAING, D. (eds.): The Works, 3, s. 357.

71 2Kr 22,3-22,20; 2 Pa 34,8-34,28. Srov. NOVOTNÝ, A.: Biblický slovník, s. 249

72 Sd 4,5; Sd 5,15. Srov. NOVOTNÝ, A.: Biblický slovník, s. 118.

73 Iz 1,1-66,24. Srov. NOVOTNÝ, A.: Biblický slovník, s. 253-254.

74 HEALEY, R.: Waiting for Deborah, s. 386.

75 LAING, D. (eds.): The Works, 2, s. 16-23.
} 
Ve Skotsku tak v podstatě vypukla násilná reformace srovnatelná s občanskou válkou, ve které proti sobě stála skotská protestantská šlechta na straně jedné a katolická šlechta podporující Marii de Guise na straně druhé. Ve jménu skotské regentky ale bojovala také francouzská armáda, která představovala takovou sílu, se kterou se skotští protestanti nemohli měřit. John Knox samozřejmě stál na straně protestantů, kterým se snažil pomoci prostřednictvím kázání namířených proti krutovládě Marie de Guise. ${ }^{76}$ Bez pomoci zvenčí ale byla skotská reformace odsouzena k zániku, a tak z hlediska dějinného vývoje může působit jako ironie, že tuto pomoc skotským protestantům poskytli právě jejich odvěcí neprrátelé a konkurenti z Anglie. Otevřená podpora jakéhokoliv povstání proti suverénní skotské královně by samozřejmě nemohla z hlediska mezinárodní politiky nikdy uspět, a to obzvláště v době, kdy se Anglie stále ještě nevymanila z problémů způsobených dřívějšími válkami a náboženskou nestabilitou posledních desetiletí. Skotská protestantská šlechta se od vypuknutí bojů proti Marii de Guise zaštitovala ochranou zájmů skotské královny Marie Stuartovny a jejích poddaných, kteří měli po dobu její nepřítomností trpět pod útlakem francouzských vojáků a Marie de Guise. Po skončení řady diplomatických jednání byla anglická vojenská podpora v podstatě vysvětlována jako pomoc a ochrana odvěkých práv souseda v nouzi, jehož svobody poškozují cizí vojáci. Tato pomoc byla samozřejmě nezbytná také proto, že právoplatná skotská královna dlouhodobě nepobývala na skotském území, a proto nemohla vědět o zvěrstvech a bezprávích, kterých se Francouzi dopouštějí na jejích poddaných. ${ }^{77}$

Anglo-skotská protestantská spolupráce vděčila za svůj vznik jak nejbližšímu rádci královny Alžběty Williamu Cecilovi, tak skotským protestantským lordům a Johnu Knoxovi. Přes všechna rizika, která toto spojenectví přinášelo, bylo nakonec dosaženo velkého vítězství. Během diplomatických jednání provázejících rok 1560 zemřela skotská regentka Marie de Guise, po jejíž smrti znesvářené strany dosáhly brzké dohody a dospěly tak k uzavření tzv. smlouvy z Edinburghu. Skotsko se tak stalo protestantskou zemí spravovanou po dobu královniny nepřítomnosti radou protestantských šlechticů. John Knox tak konečně dosáhl svého a mohl kázat beze strachu, že bude za své názory obviněn z kacírrství a upálen. Smlouva z Edinburghu znamenala mnoho také pro anglickou královnu Alžbětu, protože součástí smlouvy bylo i prohlášení Marie Stuartovny, že se zříká svých nároků na anglický královský titul. V tomto bodě je nutné dodat, že smlouva nebyla později ratifikována, ale i tak byla považována za velký úspěch, nebot́ její uzavření ukončilo krizi, ve které se Anglie potácela již od válek započatých Marií Tudorovnou. ${ }^{78}$

V průběhu roku 1560 se tak mohlo zdát, že veškerá Knoxova kritika ženských panovnic může skončit, když namísto Marie Stuartovny Skotsko spravovala protestantská šlechta a v Anglii vládla protestantská královna Alžběta. V prosinci téhož roku ale zemřel francouzský král a manžel Marie Stuartovny František II., a skotská královna se proto rozhodla navrátit do své vlasti. ${ }^{79}$ Knoxovo vysněné Skotsko tak nemělo dlouhého trvání, protože jeho ideál narušil již zmíněný př́ijezd Marie Stuartovny, jež byla stejně jako její matka katolička, která ke všemu téměř celý svůj život strávila u francouzského královského dvora. Její vazby na Francii byly nepopiratelné, což jen zhoršovalo očekávání skotské šlechty, která ještě donedávna s Francouzi bojovala. John Knox se během nadcházejících

\footnotetext{
DAWSON, J.: John, s. 182-191.

77 CLIFFORD, Arthur (eds.): The State Papers and Letters of Sir Ralph Sadler, 1. Edinburgh 1809, s. 375.

78 SUTTON, Dana (eds.): Annales, s. 54.

79 NEALE, John: Queen Elizabeth I. London 1971, s. 106-109.
} 
let s Marií Stuartovnou nejednou osobně setkal, ale výsledky těchto setkání nepřinášely prospěch ani jedné ze zúčastněných stran. ${ }^{80}$

Specifičnost a komplikovanost vztahů mezi Marií Stuartovnou a Alžbětou Tudorovnou je velmi dobře známá už kvůli dříve zmiňované otázce dědických nároků na anglický trůn. Za zmínku ale stojí, že obě královny spojovalo nepřátelství k učení a názorům Johna Knoxe, popř. k jeho Prvnímu zatroubení. Jak již bylo řečeno, tak vydání Knoxova díla vyvolalo vlnu kritiky a pohoršení, ale již nebylo zmíněno, že časem tato kritika přerostla v otevřenou obranu královen. Důvodů k těmto obranám bylo samozřejmě hned několik, snahou od zviditelnění a získání zásluh ve službách královny počínaje a touhou po naplnění politických a osobních ambicí konče. ${ }^{81}$

S ohledem na dobu, ve které se debata odehrávala, není s podivem, že převážnou většinu zúčastněných tvořili muži, ale během let se našlo i několik ženských autorek, které se k Knoxovu dílu vyjádřily. Způsob Knoxovy argumentace byl již dř́ve představen, ale jakým způsobem proti jeho práci vystupovali obránci ženského práva na vládu nad královstvím? Zásadním bodem všech obran bylo objasnění vztahu mezi genderem a mocí. Knox v podstatě tvrdil, že žena nemá žádná práva na uplatňování královské autority nad muži. Jeho oponenti se ale odvolávali na dědická práva. Kdyby totiž žena nesměla zdědit královský úřad po svém otci, v podstatě by ani nemohla přenášet dědická práva na další generaci, což by zcela zničilo dědické nároky Tudorovců na anglický trůn, protože Jindřich VII. odvozoval svá dědická práva od nároků své matky Margaret Beaufortové. To samé by platilo i pro Stuartovce, kteří své nároky na anglický trůn odvozovali od sňatku skotského krále Jakuba IV. Stuarta s Markétou Tudorovnou, dcerou Jindřicha VII. ${ }^{82} \mathrm{Ke}$ všemu bylo běžné, aby žena po otcově smrti dědila hmotný majetek, popř. jeho část, proč by tedy nemohla zdědit také jeho úřad, když zde nebyl žádný jiný mužský dědic, který by jej zastával? ${ }^{83}$ Stejně tak bylo možné klást důraz na to, že královny v podstatě jen ochraňují královský titul do chvíle, kdy jej předají do rukou svého manžela, což by nebylo ničím novým. V př́padě královny Alžběty, která se nikdy neprovdala, šlo samozřejmě o velmi specifický prípad, který byl později obhajován pro královninu neposkvrněnost a panenskou čistotu.

Knox také zdůrazňoval negativní ženské vlastnosti a př́klady ženských tyranek ze Starého zákona. Proti těmto příkladům ale obránci královen mohli použít výčet kladných vlastností a pozitivních prŕíkladů z Písma. Proti Jezábel a Atalje tak postavili Deboru a další ženy nadané prorockým nadáním, na které ve svém omluvném listu odkazoval již Jan Kalvín. ${ }^{84}$ Proti zkaženosti a neukojitelnému chtíči stavěli příklad panny, matky a světice. Na Knoxovy interpretace prvotního hříchu a Eviny podřízenosti Adamovi reagovali vlastním převyprávěním těchto příběhů, kdy Eva sice byla stvořena až po Adamovi a z Adama, ale jako lepší a dokonalejší bytost, protože se díky Adamovi Bůh poučil ze svých chyb, které v jejím případě již nezopakoval. ${ }^{85} \mathrm{~V}$ oblasti mezilidských vztahů a hierarchie autorit

\footnotetext{
80 DAWSON, J.: John, s. 210-213.

81 SHEPHARD, Amanda: Gender and Authority in Sixteenth-Century England: the Knox Debate. Keele 1994, s. 16.

82 Tamtéž, s. 15.

83 GARIN, Eugenio a kol.: Renesanční člověk a jeho svět. Praha 2003, s. 215.

84 LAING, D. (eds.): The Works, 4, s. 357.

85 SHEPHERD, Simon (eds.): The Women's Sharp Revenge : Five Women's Pamphlets from the Renaissance. London 1985, s. 39.
} 
byl kladen důraz na zásadní rozdíly mezi tím, zda se jednalo o obyčejnou ženu od rodiny, nebo o královnu. Žena byla samozrejmě stvořena k tomu, aby spíše ochraňovala domov a potomstvo, ale v manželství mohla být též partnerkou, která svému muži pomáhá nést jeho nelehký životní úděl. ${ }^{86} \mathrm{~V}$ př́padě královny se měl klást důraz na rozlišení jejích rolí: pokud byla v roli manželky a matky, tak měla být podřízena svému manželovi, který představoval hlavu rodiny; pokud se ale jednalo o roli královny, měla být skrze svou autoritu nadřazena ostatním mužům právě kvůli důležitosti vykonávaného úřadu. ${ }^{87}$

John Knox ženy panovnice často označoval řadou nehezkých jmen, čemuž se dalo bránit použitím jiných přízvisek, uměleckých jmen a vyobrazení. Anglická královna Alžběta tak vystupovala např́ílad jako Astraea, Debora a Diana. Astraea byla hvězdnou dívkou z řecké mytologie, kterou si královna Alžběta vybrala především proto, že se jednalo o panenskou bohyni spravedlnosti, čistoty a pečlivosti. Debora a její prorocké schopnosti byly již zmíněny v předchozích částech této studie. Diana byla v podstatě latinskou obdobou řecké bohyně lovu Artemidy, která byla také bohyní čistoty a panenství. Všechna zmiňovaná jména a vyobrazení tak sloužila k upevnění královnina kultu, který ji světu prezentoval jako panenskou královnu.

Jednotlivé protiargumenty a obhajoby byly velmi úspěšné a účinné, nebot' Knoxovo První zatroubení nebylo připraveno na tento druh debaty. John Knox byl výborný řečník a kazatel, a proto své dílo koncipoval ve stylu, který pro něj byl běžný. Oproti tomu práce jeho oponentů měly blíže spíše k rétorickým pracím a právním obhajobám. ${ }^{88}$ Knoxova argumentace tak byla postupem času překonána a obhajoba ženských dědických práv na královský titul natolik zesílila, že vydávání dalších kritických prací v podstatě postrádalo smysl. V praxi o něco takového nejspíše nestál ani samotný John Knox, který své kritické První zatroubení vydal za zcela jiným účelem, než jakého nakonec dosáhl. Jak již bylo řečeno, John Knox nemohl tušit, že jeho První zatroubení nepoškodí vládu Marie Tudorovny, která mezitím zemře, a že v podstatě pouze zkomplikuje nástup jediné protestantské královny, kterou za svého života poznal. Nemohl tušit, že kvůli své práci zcela ztratí vazby na své anglické přátele a rozpoutá debatu, na jejímž konci budou ženská dědická práva na královské tituly vymezena mnohem jasnějším způsobem.

\section{Závěr}

Att už si to John Knox uvědomoval, nebo ne, jeho život a tvorbu zásadním způsobem ovlivnila právě ženská vláda, kterou tak často označoval jako obludnou a tyranskou. At už se jednalo o Marii Tudorovnu, Marii de Guise, Alžbětu Tudorovnu, nebo Marii Stuartovnu, ani s jednou z těchto královen neměl John Knox dobré vztahy. Marie Tudorovna do jeho života vstoupila svými náboženskými zákony a perzekucí protestantů, která pro Johna Knoxe znamenala odchod do exilu. Marie de Guise ho sice zachránila před upálením, ale zatvrzele odmítala přestoupit k protestantismu a stejně jako všechny zmíněné Marie i ona vystupovala proti protestantům. Její vazby na Francii znamenaly, stejně jako později v případě její dcery, jasné odsouzení v očích Johna Knoxe. Jediná královna Alžběta se přiblížila jeho ideálům ženy panovnice, ale pro špatné načasování vydání svého Prvního zatroubení proti obludné nadvládě žen se pro ni Knox stal spíše nepřítelem než spojencem.

\footnotetext{
86 ORWIN, Thomas (eds.): A Preparative to Mariage, and Two Other Sermons. London 1591, s. 25.

87 SHEPHARD, A.: Gender, s. 92.

88 Tamtéž, s. 16.
} 
S žádnou z těchto královen tak Knox nevycházel v dobrém, za svá bouřlivá kázání a kritiku ženské vlády se dočkal nepřátelství a odmítnutí, ale ani navzdory řadě obranných prací k tématu ženské vlády nepřestal zastávat své názory o mužské nadřazenosti.

Jeho myšlenky a dílo tak nakonec přispěly k něčemu, co nikdy neplánoval, protože otevřely debatu o ženských právech na vládu nad královstvím, která vyznívala v Knoxův neprospěch. V př́ípadě vlády královny Alžběty Tudorovny se dokonce dalo mluvit o jasné praktické demonstraci toho, že je žena schopna vládnout velmi dobře, což dosvědčují její politické úspěchy a dlouho trvající vláda běžně označovaná jako zlatý věk. Oproti tomu se Knoxovi nedá upřít odvaha, cílevědomost a zatvrzelost, se kterou prezentoval, prosazoval a obhajoval své názory, které sice byly v některých ohledech dosti konvenční, ale v otázce oprávněnosti násilné revoluce proti tyranskému vladaři zcela revoluční.

\section{Summary}

\section{Monstrous Regiment of Women over the Life and Work of John Knox}

This study titled Monstrous Regiment of Women over the Life and Work of John Knox introduces the life and creative journey of the important Scottish reformer John Knox. Knox's life and preaching were inextricably linked and marked by his ties to the most powerful women of England and Scotland in the $16^{\text {th }}$ century - the Scottish Queen Dowager Mary de Guise, who he blamed for his confinement in the French galleys, and the English Queen Mary Tudor because of whom he was forced to leave the British Isles and go to exile. For all the wrongs and injustices committed by the above-mentioned women-queens on Knox himself or on their subjects who could not freely profess the Protestant faith because of them, Knox decided to compose a critical pamphlet The First Blast of Trumpet against the Monstrous Regiment of Women where he sought to explain why it was impossible for a woman to ascend the throne as a rightful ruler.

In his line of reasoning, John Knox did not overcome the traditionally misogynistic views of his time in any significant way. Instead, the contribution of his treatise lay in the group he was targeting. Knox's predecessors were not afraid to write about the corruption of ordinary women, but it was John Knox who did not hesitate to cross the imaginary line and dared to criticise women from the highest social classes. Nevertheless, Knox's long-term efforts eventually turned against him. Approximately half a year after his critical text was published, the Catholic queen Mary Tudor died and Protestantism returned to England along with Queen Elizabeth I.

Queen Elizabeth was fully aware of the risks posed by Knox's critical work and therefore, she banned its distribution at the very beginning of her reign. Despite his struggle against the Catholic queens, John Knox received no gratitude and never returned to England. 